\title{
The National Wind Erosion Research Network: Building a standardized long-term data resource for aeolian research, modeling and land management
}

Nicholas P. Webb ${ }^{1 *}$, Jeffrey E. Herrick ${ }^{1}$, Justin W. Van Zee ${ }^{1}$, Ericha M. Courtright ${ }^{1}$, Christopher H. Hugenholtz ${ }^{2}$, Ted M. Zobeck ${ }^{3}$, Gregory S. Okin ${ }^{4}$, Thomas E. Barchyn ${ }^{2}$, Benjamin J. Billings ${ }^{5}$, Robert Boyd $^{6}$, Scott D. Clingan ${ }^{1}$, Brad F. Cooper ${ }^{1}$, Michael C. Duniway ${ }^{7}$, Justin D. Derner ${ }^{8}$, Fred A. Fox ${ }^{9}$, Kris M. Havstad ${ }^{1}$, Philip Heilman ${ }^{10}$, Valerie LaPlante ${ }^{1}$, Noel A. Ludwig ${ }^{11}$, Loretta J. Metz ${ }^{12}$, Mark A. Nearing $^{10}$, M. Lee Norfleet ${ }^{12}$, Frederick B. Pierson ${ }^{13}$, Matt A. Sanderson ${ }^{14}$, Brenton S. Sharratt ${ }^{15}$, Jean L. Steiner ${ }^{16}$, John Tatarko ${ }^{9}$, Negussie H. Tedela ${ }^{5}$, David Toledo ${ }^{14}$, Robert S. Unnasch ${ }^{17}$, R. Scott Van Pelt $^{18}$, Larry Wagner ${ }^{9}$

${ }^{1}$ USDA-ARS Jornada Experimental Range, Las Cruces, NM 88003, USA

${ }^{2}$ Department of Geography, University of Calgary, AB, T2N 1N4, Canada

${ }^{3}$ USDA-ARS Wind Erosion and Water Conservation Unit, Lubbock, TX 79415, USA (retired)

${ }^{4}$ Department of Geography, University of California Los Angeles, CA 90095, USA

${ }^{5}$ Bureau of Land Management, San Luis Valley Field Office, Monte Vista, CO 81144, USA

${ }^{6}$ Bureau of Land Management, National Operations Center, Denver, CO 80225, USA

${ }^{7}$ US Geological Survey, Southwest Biological Science Center, Moab, UT 84532, USA

${ }^{8}$ USDA-ARS Rangeland Resources Research Unit, Cheyenne, WY 82009, USA

${ }^{9}$ USDA-ARS Agricultural Systems Research Unit, Fort Collins, CO 80526, USA

${ }^{10}$ USDA-ARS Southwest Watershed Research Center, Tucson, AZ 85719, USA

${ }^{11}$ Bureau of Land Management, California Desert District Office, Moreno Valley, CA 92553, USA

${ }^{12}$ USDA-NRCS, Resource Assessment Division, CEAP Modeling Team, Temple, TX 76502, USA

${ }^{13}$ USDA-ARS Northwest Watershed Research Center, Boise, ID 83712, USA

${ }^{14}$ USDA-ARS Northern Great Plains Research Laboratory, Mandan, ND 58554, USA

${ }^{15}$ USDA-ARS Northwest Sustainable Agroecosystems Research Unit, Pullman, WA 99164, USA

${ }^{16}$ USDA-ARS Grazinglands Research Laboratory, El Reno, OK 73036, USA

${ }^{17}$ The Nature Conservancy, Boise, ID 83702, USA

${ }^{18}$ USDA-ARS Wind Erosion and Water Conservation Unit, Big Spring, TX 79720, USA

* Corresponding author:

Nicholas Webb, Phone: 575-646-2263, Fax: 575-646-5889, Email: nwebb@nmsu.edu 
4 Abstract

5 The National Wind Erosion Research Network was established in 2014 as a collaborative effort led by the

6 United States Department of Agriculture's Agricultural Research Service and Natural Resources

7 Conservation Service, and the United States Department of the Interior's Bureau of Land Management, to

8 address the need for a long-term research program to meet critical challenges in wind erosion research

9 and management in the United States. The Network has three aims: (1) provide data to support

10 understanding of basic aeolian processes across land use types, land cover types, and management

11 practices, (2) support development and application of models to assess wind erosion and dust emission

12 and their impacts on human and environmental systems, and (3) encourage collaboration among the

13 aeolian research community and resource managers for the transfer of wind erosion technologies. The

14 Network currently consists of thirteen intensively instrumented sites providing measurements of aeolian

15 sediment transport rates, meteorological conditions, and soil and vegetation properties that influence wind

16 erosion. Network sites are located across rangelands, croplands, and deserts of the western US. In support

17 of Network activities, http://winderosionnetwork.org was developed as a portal for information about the

18 Network, providing site descriptions, measurement protocols, and data visualization tools to facilitate

19 collaboration with scientists and managers interested in the Network and accessing Network products.

20 The Network provides a mechanism for engaging national and international partners in a wind erosion

21 research program that addresses the need for improved understanding and prediction of aeolian processes

22 across complex and diverse land use types and management practices.

24 Keywords: wind erosion, aeolian, dust emission, monitoring, network, Long-Term Agroecosystem 25 Research

\section{Introduction}

28 Land use and land cover change have potentially massive impacts on global rates of wind erosion and 29 dust emission (Neff et al., 2008; Marx et al., 2014). Together, these aeolian sediment transport processes 30 influence climate, ecosystem dynamics and land productivity (Ravi et al., 2011). Dust emissions from

31 disturbed surfaces can impact air quality, human health and transportation systems (Sharratt and Lauer, 32 2006; Sprigg et al., 2014). Wind erosion can moderate the effectiveness of climate change mitigation and 33 adaptation strategies, and contribute significantly to the global cost of land degradation (ELD Initiative, 
2015). Land managers require information on wind erosion to assess the impacts of policy and management strategies and the economics of remedial action or inaction.

Managing and planning for the impacts of wind erosion requires an understanding of the underpinning sediment transport processes and their interactions. This understanding is derived from field and laboratory studies of aeolian processes (e.g., Zobeck et al., 2003), and through conceptual and numerical models that explore interactions with biogeochemical, ecological and human systems (e.g., Shao et al., 2011a). Application of this understanding requires that knowledge of aeolian processes can be reliably up-scaled to represent the many complex dynamic interactions within fields, across regions, and globally (Raupach and Lu, 2004). Predictive models, developed from theory and empirical observation, play an important role in up-scaling process understanding.

While numerous aeolian sediment transport models exist, their direct application to policy, planning and decision making has been limited. Considerable attention has been given to modeling wind erosion in croplands (e.g., Tatarko et al., 2013; Wagner, 2013; Sharratt et al., 2015). Nonetheless, many model applications have been driven more by scientific questions and hypothesis testing than to inform management or policy. Synthesizing complex systems knowledge in models is effective to identify knowledge gaps and investigate the nature of fine $(\mathrm{cm})$ and broad $(\mathrm{km})$ scale aeolian processes and interactions (Shao et al., 2015). However, integrating results of aeolian research to inform management and policy has met with a number of important and non-trivial challenges.

The first major challenge for wind erosion modeling, management, and policy development has been the use of non-standardized methods in field studies and monitoring programs, which makes it difficult to compare results and outcomes across land use systems (Barchyn et al., 2011). Flexibility in research methods, including data collection and analysis, is clearly necessary to meet individual study needs and to increase basic scientific understanding. However, in many cases the long-term benefits of methods standardization outweigh the costs (Toevs et al., 2011). Without standardized methods, for example in measuring sediment transport rates and atmospheric conditions, it is very difficult to derive robust regional or national scale assessments of wind erosion and dust emission from existing data. Consequently, knowledge of the magnitude and relative rates of wind erosion and dust emission across land cover types, their likely responses to land use and management change, and sensitivity to climate variability and change remains limited (Flagg et al., 2014).

Second, many monitoring studies have been limited by sampling designs that lack statistical rigor and reveal little about the spatial and temporal variability in sediment transport that drives patterns of 65 wind erosion and dust emission (e.g., Chappell et al., 2003). Without knowledge of the variability 66 (including within-site and between-site variances) in sediment transport, it is very difficult to elucidate 67 differences in wind erosion across land use and land cover types, or in response to management 
treatments or other environmental perturbations (e.g., Belnap et al., 2009). Development of management strategies and policy on the basis of limited measurements in space and time can be risky (Herrick et al., 2010). Knowing data representativeness, accuracy, and precision is also critical for testing predictive models, which in the absence of reliable and scalable monitoring data often serve as the basis for wind erosion assessments and planning (e.g., Leys et al., 2010; Wagner, 2013; Borelli et al., 2014).

A third limitation to wind erosion modeling, management and policy development is the availability of quality data for assessing model performance. Indeed, many aeolian sediment transport models have not undergone rigorous accuracy assessment due to the lack of appropriate data (Shinoda et al., 2011). Despite efforts to test models against field data (e.g., Shao et al., 2011b; Li et al., 2013), uncertainty in model outputs is largely unknown. Application of wind erosion and dust emission models for decision making requires an understanding of uncertainty so that model outputs can be interpreted to appropriately manage the risk of adverse decisions (Walker et al., 2003). Model evaluation through assimilation of surface air quality observations and satellite imagery has improved the situation by providing supporting information on sediment transport rates (e.g., Leys et al., 2008; Yumimoto et al., 2008), but has yet to provide the necessary user confidence in regional, national or global simulations. Robust model evaluation requires that the frequency and magnitude of sediment transport estimates from models have been tested in space and time, across the range of intended application environments, and are conducted using methods that are informative to the application (Rykiel, 1996). This requires consistent and high quality measurements of aeolian sediment transport rates and the factors that control them. Unfortunately, the cost of data collection to conduct such analyses is often prohibitive for individual studies. Decision makers undoubtedly discount the power of modeling when output accuracies are unknown or unreported.

Finally, the selection of models that can be used to assess wind erosion and dust emission presents a challenge for land managers and policy makers. Aeolian sediment transport models have traditionally been developed to assess gross or net wind erosion from agricultural fields (Tatarko et al., 2013; Wagner, 2013), or horizontal and vertical sediment mass fluxes (Marticorena and Bergametti, 1995; Shao, 2008). There are fundamental conceptual differences between wind erosion (soil loss), which is often of interest to land managers, and the sediment mass fluxes output by most models; as well as practical differences in how the processes are represented in models and applied to inform management or policy. Extension of wind erosion concepts and models to rangelands and deserts is particularly challenging because these settings have poorly defined or non-existent 'field' boundaries (Li et al., 2014), aeolian processes appear to be dominated by soil redistribution at different spatial scales (Okin et al., 2015), and current knowledge

100 (Durán et al., 2011), and sediment deposition by interception with roughness features (Raupach and Lu, 101 2004). Differences in how the models have been parameterized, their inputs, and scales of application (Li 
et al., 2014) can also be confusing and have likely created a barrier to their application. Managers and policy makers wishing to assess aeolian sediment transport across land use types, land cover types, and in response to climate change require a well-documented, accessible, and generalizable model that represents with sufficient fidelity the processes that control aeolian sediment transport in different environments.

Addressing these limitations to wind erosion research and model applications presents many opportunities for the aeolian research community to increase its regional, national and global impact. These opportunities stem from challenges of developing standardized methods for aeolian research that can be applied through statistically rigorous sampling designs, across land use and land cover types, to provide data that can significantly improve measurement, monitoring, and modeling of aeolian processes and their application in decision making. Development of a long-term networked research program can provide a mechanism for targeting these important challenges and ensure that research results and outcomes have greater impact for society.

This paper presents the National Wind Erosion Research Network - a new long-term national research network in the United States, developed through a multi-partner collaboration to address critical challenges in aeolian research and management. We introduce the Network objectives and predicted benefits (Section 2), describe the standardized measurement methods and sampling design (Section 3), and provide a brief description of the currently instrumented sites (Section 4). We then detail the Network Data Portal (http://winderosionnetwork.org; Section 5) and end with a section promoting increased collaboration (Section 6) and an open invitation to institutions around the world to join the Network (Section 7).

\section{Long-Term Networked Aeolian Research and its Benefits}

The National Wind Erosion Research Network was conceived as a multi-partner collaborative effort to address the need for a standardized, long-term, and networked research program to meet wind erosion science and management challenges. The Network has three overarching objectives: (1) provide data to support understanding of basic aeolian processes across land use and land cover types and for different management systems, (2) support the development of models to assess wind erosion and dust emission that are available to the scientific community and land management agencies, and (3) encourage collaboration among the aeolian research community, resource managers and policy makers to develop opportunities for furthering the science and its application to understanding and managing the impacts of wind erosion.

The National Wind Erosion Research Network sites (Figure 1) were established and are managed with support from the US Department of Agriculture's Agricultural Research Service (ARS) and Natural 
137 (BLM) and US Geological Survey (USGS), the Department of Defense (DoD), and The Nature 138 Conservancy (TNC). The National Wind Erosion Research Network is a core program of the USDA-ARS 139 Long-Term Agroecosystem Research (LTAR) network (Robertson et al., 2008) and is coordinated 140 through the USDA-ARS Jornada Experimental Range in Las Cruces, New Mexico. Many of the LTAR 141 Network sites also participate in the Soil Climate Analysis Network (SCAN; Schaefer et al., 2007), 142 GRACEnet (Jawson et al., 2005), the Long Term Ecological Research (LTER) network (Hobbie et al., 143 2003), and the National Ecological Observatory Network (NEON; Keller et al., 2008). The National Wind 144 Erosion Research Network aims to have similar longevity and impact on understanding processes and 145 managing agro-ecosystems as these established long-term research programs.

Methods standardization, data collection and data sharing through long-term research networks provide many benefits. These include the ability to address basic research questions at the individual site scale, while contributing to cross-site comparisons and analyses. These comparisons and analyses can reveal broad (landscape to regional) scale patterns and interactions that may not be detectable at the site scale, and are directly relevant to the scales of many land management decisions (Hobbie et al., 2003). Long-term research networks also provide a platform, through data sharing, infrastructure and skills, for developing collaborations and greatly increasing our understanding of system function. These were central goals in establishing the Network.

154 Examples of the diverse research questions currently being addressed through the National Wind Erosion Research Network include:

156 1. What is the spatial variability in aeolian sediment transport and what are appropriate sampling resolutions for measuring and monitoring wind erosion across land use and land cover types?

2. How can remote sensing technologies (airborne and spaceborne) be applied in new ways to measure land surface aerodynamic properties for integration into monitoring programs and models?

3. How can the effects of land management on aeolian sediment transport be captured in physicallybased and generalizable numerical models that have application across land cover types?

4. How can the accessibility of wind erosion/dust emission models to resource managers be improved to inform decision making, planning and policy?

167 partners (e.g. BLM and NRCS) as to projected management and research needs, the Network will produce 168 novel outcomes for basic and applied aeolian research across land use systems and across scales. This 169 impact is particularly relevant today during a time of global environmental uncertainty arising from 
intensifying land use pressures, land degradation, and increasing climatic variability and climate change.

171 Mitigating and adapting to these changes requires an understanding of the biophysical drivers, and the

172 capacity to act through management strategies and policy in ways that promote ecosystem goods and

173 services and the diverse socio-economic and cultural systems that depend on them. As a platform for

174 integrating aeolian research with land management, the Network will directly support efforts to develop

175 sustainable systems that are adaptive, productive, and resilient to change.

\section{Methods Standardization and Network Design}

178 Methods standardization underpins the research and monitoring activities of the National Wind Erosion

179 Research Network. Consistency in data collection is critical for the success of networked and long-term

180 studies, in evaluating sediment transport processes within and between study sites, and in model

181 calibration and testing. Additionally, systems for quality assurance and quality control through data

182 collection, data management, and interpretation are essential (Herrick et al., 2015).

To provide guidance for Network activities, a standard methods protocol was developed that defines procedures for (1) site characterization, (2) site design and layout, (3) meteorological and wind erosion threshold measurements, (4) measurement of sediment mass flux, and (5) land surface measurements including vegetation, soils and land management (Webb et al., 2015). These protocols are followed at all Network sites. The document identifies a core set of standard methods for assessments of wind erosion and its controlling factors. These core methods generate the minimum data required to evaluate spatiotemporal patterns of sediment transport within sites and to calibrate and quantitatively test (validate) wind erosion models. The methods include measurements of the first-order controls on aeolian sediment transport processes (emission and deposition), and are integrative of the many factors that influence them.

192 Focus is given to accurate and cost-effective collection of data with sufficient precision for modeling.

193 Some of the protocols will adjust with time according to research and technical innovations. Accordingly,

194 the standard methods protocol (Webb et al., 2015) is a living document and will be reviewed and updated 195 at 5-10 year intervals.

196 Utilizing existing standardized approaches ensures familiarity among scientists and land managers 197 with the sampling methods and data. It will also dramatically increase application of the Network data 198 and models to be used with existing monitoring programs, allowing scientists to leverage these existing 199 datasets. For example, the USDA National Resources Inventory (Goebel, 1998) and BLM Assessment, 200 Inventory and Monitoring (AIM) Strategy (Toevs et al., 2011) apply the majority of the same soil and 201 vegetation monitoring methods as used by the National Wind Erosion Research Network at $>15,000$ 202 locations across the United States. These provide a source of scalable information that can support 
aggregated (regional to national) assessments of wind erosion in the United States and spatial model applications, while maintaining data confidentiality as appropriate.

The Network standard methods protocol also provides a set of supplementary methods. While limited in scope, these optional methods can be used to provide more comprehensive data on sediment transport rates and their controlling factors, including soil surface characteristics (e.g., aggregate size distribution and random roughness) that influence wind erosion. While the core methods support baseline data collection at Network sites, it is intended that the supplementary methods be used to support individual studies or interests that use the Network as a research platform.

\subsection{Network site design and instrumentation}

213 The National Wind Erosion Research Network site design was developed to provide detailed 214 measurements of aeolian sediment transport and its controlling factors in a way that overcomes 215 limitations of traditional aeolian process studies, which tend to sample inadequately in space (Chappell et 216 al., 2003), and often over relatively short periods of time (e.g., <5 years). No previous studies in the 217 United States have collected long-term samples of aeolian sediment transport (including saltation, suspension, and deposition) across diverse land use and land cover types, together with similarly detailed measurements of soil properties, vegetation, and land management, using statistically rigorous sampling designs to address the big challenges for aeolian research (Section 1).

Network sites each occupy a $100 \mathrm{~m}$ x $100 \mathrm{~m}$ area, located in landscape settings that have relatively homogeneous land cover (soil type and vegetation community) and management (Figure 2). The site unit area was chosen to provide the largest practically-measurable space that would enable: (1) detection of spatial variability in sediment transport responsible for local (within site) erosion and deposition; (2) analysis of controls on the variability in transport due to patterns of vegetation structure and distribution and soil surface conditions; (3) collection of data at a scale that is relevant to management practices in both croplands and rangelands; and (4) measurement by moderate (e.g., $30 \mathrm{~m})$ to high $(<10 \mathrm{~cm})$ resolution airborne and satellite remote sensing for integration with spatially distributed models. The selection of site locations that have homogeneity in soil type and vegetation (allowing for within-site roughness heterogeneity) ensures that complexity in the dynamic controls on sediment transport can be studied without the potentially confounding effects of significant differences in soil erodibility and aerodynamic

232 roughness that occur over varied terrains and across land cover boundaries (Figure 3). All instrumentation 233 and sampling to measure atmospheric conditions, sediment transport rates, and soil and vegetation 234 properties are distributed within the $100 \mathrm{~m}$ x $100 \mathrm{~m}$ sites. Here we provide an overview, while full details 235 are available in Webb et al. (2015). 
238 Aeolian research, monitoring and model development (including calibration and testing) require 239 measurements of meteorological conditions that influence the erodibility of soils, surface roughness, and 240 drive sediment transport. Core Network measurements include: rainfall, relative humidity, a temperature 241 profile, a wind velocity profile, and saltation activity. These variables are used to estimate the 242 aerodynamic roughness height $\left(z_{0}\right)$ of the surface, the wind friction velocity $(u *)$ and the threshold friction 243 velocity $\left(u_{*}\right)$ for soil entrainment (Zobeck et al., 2003).

To acquire these data, each site is equipped with a centrally located $10 \mathrm{~m}$ instrument tower on which are mounted sensors to measure wind speed and direction, air temperature, relative humidity, rainfall, and saltation activity (Figure 4). Full details of the instrumentation and their deployment are provided in Table 1. All instruments are controlled using Campbell Scientific CR1000 data loggers with onsite back-up to a memory card. Sampling is conducted at $1 \mathrm{~Hz}$ and data are logged as averages, maximums and standard deviations at a 1 min frequency. Data are transmitted hourly from each site by digital cellular modem (RAVENXTV) and Code Division Multiple Access (CDMA) network to a server maintained at the USDA-ARS Jornada Experimental Range in Las Cruces, NM. Data logger programs for any site can be accessed and updated from the server, streamlining error detection, maintenance and data management across the Network.

\subsubsection{Sediment mass flux measurements}

Measurements of horizontal (saltation) and vertical (dust) emission and deposition are required to ascertain the net sediment mass flux at the National Wind Erosion Research Network sites. Horizontal mass flux is included as a core measurement at Network sites. The vertical mass flux, derived from a mass concentration (size 0.1 to $10 \mu \mathrm{m}$ ) profile measured with two DustTrak ${ }^{\mathrm{TM}}$ DRX light-scattering laser photometers (model 8533), will be included at all sites once instrumentation is available. These instruments collect data at the same sampling $(1 \mathrm{~Hz})$ and logging (1 minute) intervals as the meteorological sensors and data can be written directly into the output meteorological data tables (Table $1)$.

Selection of instrumentation for sampling horizontal sediment mass flux was based on (1) efficiency 266 Cooke (MWAC) samplers were selected as the standard for measuring horizontal sediment mass flux 267 (Figure 4). Technical descriptions of the samplers and their efficiencies are contained in Shao et al. 268 (1993), Goossens et al. (2000), and the Network standard methods protocol (Webb et al., 2015).

Detecting the spatial variability in sediment mass flux is essential for improving our understanding 270 of aeolian sediment transport processes (emission, transport and deposition) and quantifying net soil 
redistribution (Chappell et al., 2003). This information will be key for developing net wind erosion

272 models that function across land use and land cover types. A strong sampling design is also required to

273 make statistically robust comparisons of sediment transport across systems, but has arguably been lacking

274 from previous wind erosion monitoring programs. In the absence of knowledge about the spatial

275 variability in sediment transport, sampling at Network sites is targeted specifically to evaluate the

276 transport variance following established cost-effective protocols for measuring the spatial variability in

277 soil redistribution ( $\mathrm{Li}$ et al., 2015). A spatially-stratified random sampling design is used to measure

278 horizontal sediment mass flux (Figure 2). Network sites are divided into a virtual 3 x 3 grid, in which

279 each of the 9 cells $(\sim 33 \mathrm{~m} \mathrm{x} 33 \mathrm{~m})$ contains three randomly located rotating MWAC sampler masts

280 (totalling 27 masts per site) holding four sampler bottles at $0.1 \mathrm{~m}, 0.25 \mathrm{~m}, 0.5 \mathrm{~m}$ and $0.85 \mathrm{~m}$ heights. The

281 design is used consistently across the Network irrespective of land cover type. MWAC mast locations that

282 fall in the middle of a plant canopy are rejected and then relocated to another random location within the

283 grid cell. This ensures that measurements are made both adjacent to vegetation and within plant-canopy

284 interspaces, thereby capturing the within-site variability in sediment mass flux.

285 Dust deposition is included as a supplementary measurement, but is encouraged across all Network

286 sites. The dust deposition flux is measured using marble trap samplers following the design of Reheis and

287 Kihl (1995). When deployed, three dust deposition traps mounted at $1.5 \mathrm{~m}$ height are randomly located

288 within the $100 \mathrm{~m} \times 100 \mathrm{~m}$ sites (Figure 2).

Spatial variability in sediment mass flux

291 Preliminary data from the USDA Jornada Experimental Range provide insights to the nature of spatial

292 variability in vertically integrated horizontal sediment mass flux and a starting point for analysing 293 spatiotemporal patterns of wind erosion across land cover types represented by the Network. Summary

294 statistics (Table 2) show the considerable spatial variability that may exist in sediment mass flux. The 295 distribution of sediment transport was highly skewed in each month, and up to two orders-of-magnitude 296 difference in sediment mass flux was measured across the site. Possible drivers of this variability include 297 the site's heterogeneous sediment supply and surface roughness, interacting with intermittent momentum 298 transfer to the surface due to turbulence in the atmospheric boundary layer (Shao et al., 2015). The data 299 also show the strength of the Network sampling design. Deployment of a small number $($ e.g. $\leq 3)$ of 300 sediment samplers in non-random locations, as often used in monitoring programs, would be unlikely to 301 consistently capture the variability in sediment mass flux and reduce the power of the data to reveal the 302 magnitude and dynamics of wind erosion across the Network sites.

$304 \quad 3.1 .3$ Vegetation and soil surface measurements 
Vegetation and non-erodible roughness (e.g., rocks) protect the soil surface by influencing the erodible area of a landscape and the wind shear stress that can act on exposed soil surfaces (Gillette, 1999). The cover, distribution and height of vegetation and other non-erodible roughness elements determine their effectiveness in moderating the initiation of sediment transport (Okin, 2008), the sediment mass flux (Webb et al., 2014), and sediment deposition rates (Raupach et al., 2001). The cover and distribution of soil aggregates, loose erodible material (LEM), soil surface moisture, and physical and biological soil crusts influence the soil entrainment threshold (Zobeck, 1991; Webb et al., 2016) and the magnitude of sediment transport (Macpherson et al., 2008). Measurements of these attributes follow the standard methods of Herrick et al. (2015) and include: Line-point intercept (LPI) for fractional foliar cover of vegetation by species and soil surface properties (physical and biological crusts, soil aggregates, fragments, LEM); vegetation canopy gap for the size and distribution of bare inter-canopy spaces; and vegetation height.

Vegetation and soil surface measurements are made along three $100 \mathrm{~m}$ transects with $60^{\circ}$ spacing, intersecting at $50 \mathrm{~m}$ in the center of the sites (Figure 2). The transect design enables directional measurements of vegetation and dynamic soil surface properties to be acquired in an efficient way that is repeatable, representative of the entire site, scalable to estimates of vegetation cover from remote sensing platforms (e.g., Landsat), and can be related to directional measurements of $z_{0}$ and $u_{*}$ derived from the meteorological tower data. Photographs are taken in both directions down all transect lines at the time of every survey. LPI measurements are made every $0.25 \mathrm{~m}$ along the transects (1200 points) and vegetation height measurements are made every $2.0 \mathrm{~m}$ (150 points), providing a high resolution sample of the roughness characteristics, soil crusting, and availability of loose erodible soil for entrainment by wind.

\subsubsection{Soil sampling design}

328 Measurements of soil biological and physical properties are necessary for interpreting controls on the soil

329 entrainment threshold, dynamic soil surface characteristics such as crusting, aggregation and availability 330 of LEM, and sediment transport rates and their impacts (Zobeck et al., 2003). A robust sampling design is 331 therefore needed to ensure that the spatial variability in soil properties is represented in the data. Soil 332 sample collection at the Network sites follows a protocol established by Chappell et al. (2015) for cost333 effective sampling of soil properties for geostatistical mapping. A spatially-stratified random sampling 334 design of $3 \times 3$ cells each containing three samples, like that used for locating the MWAC sediment 335 samplers (Figure 2), is employed.

336 At the time of site establishment, $27 \mathrm{x} \sim 150 \mathrm{~g}$ samples of the uppermost $0.01 \mathrm{~m}$ (i.e., soil surface) are 337 collected from all sites for later analysis of the soil particle size distribution (texture), fragment volume 338 and size distribution, soil organic carbon $(\mathrm{SOC})$, total nitrogen $(\mathrm{N})$, and calcium carbonate $\left(\mathrm{CaCO}_{3}\right)$ 
contents. Repeat soil sampling at the sites will be conducted to monitor changes in texture due to

340 sediment erosion and deposition and for application in monitoring net soil redistribution (e.g., using ${ }^{137} \mathrm{Cs}$

341 techniques).

\subsubsection{Land management records}

344 Local land management and disturbance events (e.g., fire) can have significant impacts on soil erodibility 345 and vegetation and can therefore be an important driver of wind erosion (Ravi et al., 2010). Records of

346 land management activities and disturbance are kept for Network sites as part of the core metadata 347 collection. For croplands, these records include the type, timing and depth of tillage, planting and 348 harvesting operations, irrigation (methods and rates), herbicide and fertilizer applications, the impacts of management on soil oriented roughness (tilled soil ridge height, spacing and aspect), aggregate size distribution, and any livestock grazing that may occur onsite. For rangeland sites, records of land management activities include livestock types, stocking rates, timing and duration of grazing, fencing, livestock water points, wild fires and prescribed burning, herbicide or mechanical vegetation removal, seeding, and notes on other activities that have affected the site condition (e.g., extreme weather events). Each Network site also has a digital time-lapse camera (Table 1) mounted on the meteorological tower, set to take at least five oblique photographs per day. These data, while largely qualitative, provide valuable insights to the condition of the Network sites over time; they provide evidence for interpreting changes in vegetation and snow cover, the erodible sediment supply, entrainment threshold and aerodynamic roughness that are needed to elucidate the effects of land management on trends in sediment transport rates over time.

362 Currently, thirteen sites are actively involved in the National Wind Erosion Research Network (Figure 1). 363 The site locations represent the range of soil types, vegetation communities (species compositions, 364 structures and distributions) and land use activities occurring in areas that are susceptible, or may be 365 susceptible in the future, to wind erosion. The sites include croplands, rangelands, and deserts that are used for food and fiber production, energy development (oil, gas and solar), recreational activities, and agricultural research. Table 3 provides a summary of the Network site soils, vegetation and land management characteristics.

In accordance with the goals of the Network (Section 2), some of the sites, such as those in New

371 transport and its impacts and interactions with dryland ecosystems (e.g., Bergametti and Gillette, 2010;

372 Flagg et al., 2014) and agricultural production (e.g., Van Pelt et al., 2004; Sharratt and Vaddella, 2012). 
This research provides useful context for further developing the science underpinning wind erosion models and management at these locations, and extending that understanding to interpret processes at the other sites. Nevertheless, this previous research has lacked the broad coordination provided by the Network that is required to develop models and management strategies across spatial and temporal scales. The remaining Network sites are located in areas that have received relatively less attention from the aeolian research community. However, all sites are impacted by land use or land management challenges that critically influence wind erosion processes in these landscapes.

Management of landscapes in which the Network sites are located (Table 3) is as diverse as the soils and vegetation. Sites that are associated with the USDA Long-Term Agroecosystem Research (LTAR) network are open to management manipulation and disturbance treatments, providing unique opportunities to explore the effects of land use and/or land cover change on wind erosion and dust emission and the skill of numerical models in representing these changes (e.g., Li et al., 2013). Multiple instrumented sites may be installed at some of the Network locations (e.g., Central Plains Experimental Range, $\mathrm{CO}$ and Reynolds Creek Experimental Watershed, ID), enabling wind erosion assessments to be integrated with common experiments designed to assess ecologically-sustainable approaches to agricultural intensification. Developing the capacity to assess the wind erosion consequences of land management actions that drive land cover change (e.g., grazing, cultivation of rangelands, shrub/brush removal treatments, and abandonment of cropland) is a key motivation for the Network. Understanding the ramifications of such management actions is anticipated to become even more important under changing land use pressures, increasing climate variability, and climate change (Robertson et al., 2008).

\section{Data Acquisition and Data Storage}

\subsection{Data collection}

396 Network data collection frequencies vary depending on data type (e.g., weather, management), while 397 baseline (core) measurements have a minimum standard frequency that is implemented across all sites 398 (Webb et al., 2015). Developing these standards inevitably involved trade-offs between the data 399 resolution required to resolve process information from the measurements (i.e., the time-scale of sediment 400 transport) and the time available for technical staff to access sites under variable climatic conditions, 401 conduct data sampling and quality control, and transmit data to the centralized Network server.

402 Meteorological and dust concentration data are logged at $1 \mathrm{~min}$ intervals (Table 1). Measurements of 403 the horizontal sediment mass flux are made once per month, which along with measurements of 1 min 404 sediment transport from the Sensit saltation impact sensors provide data on the monthly magnitude and 405 approximate frequency of sediment transport. The low temporal resolution of mass flux measurements, 406 however, makes it important that data are collected on schedule for the Network to enable process- 
response analyses and long-term data comparisons among sites. Collection of the MWAC samples to measure sediment transport at a higher temporal resolution is at the discretion of individual sites as needed (e.g., on an event basis). Dust deposition traps are collected at a minimum of every three months. This sampling resolution provides the smallest detectable sample size at many of the Network sites.

Vegetation surveys at Network sites are conducted at a minimum of four times per year. Timing of the surveys is adjusted for each Network site to capture the seasonal changes in vegetation cover, 413 phenology and structure, and soil surface conditions. Time-lapse photography (Table 1) provides a visual

414 reference for the changing site conditions and an indicator of vegetation phenological responses to guide 415 survey timing.

416 Quality assurance in data collection is provided through training at all sites following initial 417 equipment installation. The training covers soil, sediment, meteorological and vegetation measurements, and includes calibration of field personnel to the vegetation survey methods (Herrick et al., 2015) to remove any perceived subjectivity and provide guidance on thresholds and nomenclature. All vegetation species are recorded using the standardized USDA PLANTS Database (http://plants.usda.gov/) species codes. Sampling protocols for each of the data types can be accessed online through the Network website (http://winderosionnetwork.org/documents).

\subsection{Centralized data management}

425 The National Wind Erosion Research Network has a centralized data management system housed at the USDA-ARS Jornada Experimental Range. The system can be accessed externally by Network members and collaborators who wish to either upload or download data through the online Network Data Portal (http://winderosionnetwork.org/data-portal). The benefits of maintaining a centralized database include maintaining data quality assurance through checks on data collection, ensuring data quality control standards are met, archiving data for future use, and making data easily accessible to Network members, collaborators and the general public.

All data collected following the Network core methods are managed in standard formats that provide consistency across the sites. Metadata associated with the records are included in the data files, and include the site management records and site equipment records that detail technical issues and provide maintenance logs on the meteorological equipment and sediment samplers. Raw meteorological data are transmitted directly to the Network server and Data Portal via wireless network where they are stored in comma-separated values (.csv) file format. Geographic information associated with the Network sites is

438 stored and made accessible as ArcGIS Geodatabases and Google Earth compressed Keyhole Markup 439 Language $(. \mathrm{kml})$ files. Photographs of vegetation transects and from the time-lapse cameras are stored and 440 available in compressed folders organized by calendar months across years. 
Soils, vegetation and sediment mass flux data are stored in the Database for Inventory, Monitoring and Assessment (DIMA), a customizable Microsoft Access database that enables data collection, 443 management, and interpretation (Courtright and Van Zee, 2011). The use of DIMA, and methods of 444 Herrick et al. (2015), by the BLM AIM Strategy makes those data directly relevant to the Network and 445 the Network research and models transferable to that national monitoring strategy (Toevs et al., 2011). 446 USDA PLANTS species codes can be uploaded into the DIMA for each Network site, streamlining 447 vegetation sampling and reducing plant identification and data entry errors. Data from multiple sites can 448 be merged into a single DIMA, which can then rapidly generate reports on soils, vegetation (foliar cover, 449 distribution, height and species composition), site descriptions and management records, as well as 450 summaries of sediment flux and dust deposition data, which can be customized for assimilation with 451 available wind erosion models (e.g., Okin, 2008; Shao, 2008).

\section{Data Access: Promoting Collaboration}

454 The National Wind Erosion Research Network operates an open network and encourages collaboration through infrastructure and data sharing, in addition to creating opportunities for new sites to join the Network. This includes the opportunity to expand from a national to an international Network. Any researcher wishing to collaborate with Network sites can establish contact through the personnel directory provided on the website (http://winderosionnetwork.org/personnel). While Network sites follow a standardized data collection protocol, this should not be seen as a barrier to researchers wishing to use one or more sites as a platform for other related research. The costs associated with establishing and maintaining instrumented research sites are often high. Utilizing existing Network infrastructure to conduct research may provide opportunities to collect and work with data from diverse climate zones, land cover types, and land use systems that may otherwise not be available.

The National Wind Erosion Research Network is committed to providing access to data collected as part of Network activities to all stakeholders, collaborators and the general public. Access to the Network data is controlled by resource/data type to protect collaborator research and publishing requirements and sensitive information regarding the location of some Network sites (e.g., on military land). All raw meteorological data are publicly available from the time of acquisition. Data visualization tools (e.g., Figure 5) are provided online (http://winderosionnetwork.org/network-sites) to view the Network site locations and summaries of the latest meteorological observations. These include current temperature and relative humidity, a wind rose showing the distribution of $10 \mathrm{~m}$ wind speed and direction over the last 24 hours, graphs summarizing daily rainfall, the 1 min average wind speed, and total Sensit saltation particle counts. Access to all soils, vegetation, land management and sediment mass flux data is initially restricted to Network collaborators; after three years from collection the data will be made available to the public. 
Access to the Network data is subject to acceptance of a Data Use Agreement, which ensures that potential collaborators have established communication and an agreement with any sites they wish to work with on how resources/data will be used, and that any contributions from sites (e.g., infrastructure, data, and/or expertise) are acknowledged appropriately.

Maintaining momentum and consistency in data collection for the National Wind Erosion Research Network will be important for its longevity and impact as a leading resource for aeolian process studies and modeling. This is likely to be enhanced as data and analyses from the sites bring new insights to aeolian research and its interactions with land management. The Network research and impact for regional dust transport monitoring and modeling may be broadened through collaboration with air quality and aerosol monitoring networks, such as the US Interagency Monitoring of Protected Visual Environments (IMPROVE), the Clean Air Status and Trends Network (CASTNET), and the Aerosol Robotic Network (AERONET). We also hope to attract external collaborators to engage with the Network and establish new projects using Network resources.

\section{Summary and Outlook}

Establishing a standardized, long-term data resource through the National Wind Erosion Research Network presents opportunities for novel, high-impact research and new collaborations. These opportunities lie in developing our understanding of aeolian processes and addressing critical management challenges from local to national scales. The thirteen National Wind Erosion Research Network sites currently established span diverse rangelands, croplands, and deserts across the western United States. Data from the Network will enable new research questions to be addressed about the patterns and processes of wind erosion and dust emission, the magnitude and variability of aeolian sediment transport responses to land use change, land cover change and climate change, and the development of robust models and decision support tools for land managers. The Network strength will be evidenced by the development of long-term data and analyses, as well as the new insights and knowledge that these data and activities provide.

To that end, we invite other locations around the world to engage with the Network and to adopt the standardized methods described here (Webb et al., 2015). As resources allow, we will also promote expansion of the number of formal Network locations and make the data available through the online Network Data Portal.

\section{Acknowledgements}

Funding and in-kind support for the National Wind Erosion Research Network were provided by the USDA Agricultural Research Service and Natural Resources Conservation Service, the DOI Bureau of 
Land Management and US Geological Survey, Department of Defense and The Nature Conservancy. Development of the Network was a large collaborative effort and thanks are given to the many technical staff and administrators involved in site selection and permitting, procuring resources, installing

512 equipment and data collection. Special thanks are given to Adrian Chappell (CSIRO, Australia) for 513 discussions about sampling designs and the manuscript, and David Smith (USDA-ARS, Rangeland

514 Resources Research Unit) for his tireless efforts in managing technical issues at the Central Plains 515 Experimental Range. Any use of trade, product, or firm names is for descriptive purposes only and does 516 not imply endorsement by the US Government.

\section{References}

519 Barchyn, T.E., Hugenholtz, C.H., Ellis, J.E., 2011. A call for standardization of aeolian process measurements: moving beyond relative case studies. Earth Surface Processes and Landforms 36, 702705.

Belnap, J., Reynolds, R.L., Reheis, M.C., Phillips, S.L., Urban, F.E., Goldstein, H.L., 2009. Sediment losses and gains across a gradient of livestock grazing and plant invasion in a cool, semi-arid grassland, Colorado Plateau, USA. Aeolian Research 1, 27-43.

Bergametti, G., Gillette, D.A., 2010. Aeolian sediment fluxes measured over various plant/soil complexes in the Chihuahuan desert. Journal of Geophysical Research 115, F03044, doi:10.1029/2009JF001543, 2010.

Borelli, P., Panagos, P., Ballabio, C., Lugato, E., Weynants, M., Montanarella, L., 2014. Towards a panEuropean assessment of land susceptibility to wind erosion. Land Degradation and Development doi: 10.1002/ldr.2318.

Chappell, A., McTainsh, G.H., Leys, J.F., Strong, C.L., 2003. Using geostatistics to elucidate temporal change in the spatial variation of aeolian sediment transport. Earth Surface Processes and Landforms $28,567-585$.

Chappell, A., Li, Y., Yu, H.Q., Zhang, Y.Z., Li, X.Y., 2015. Cost-effective sampling of ${ }^{137}$ Cs-derived net soil redistribution: Part 2-estimating the spatial mean change over time. Journal of Environmental Radioactivity 144, 168-174.

Courtright, E.M., Van Zee, J.W., 2011. The Database for Inventory, Monitoring, and Assessment (DIMA). Rangelands 33, 21-26.

Daly, C., Taylor, G.H., Gibson, W.P., Parzybok, T.W., Johnson, G.L., Pasteris, P.A., 2001. High-quality spatial climate data sets for the United States and beyond. Trans. ASABE 43, 1957-1962.

Durán, O., Claudin, P., Andreotti, B., 2011. On aeolian transport: Grain-scale interactions, dynamical mechanisms and scaling laws. Aeolian Research 3, 243-270. 
ELD Initiative, 2015. The Value of Land: Prosperous lands and positive rewards through sustainable land management. The Economics of Land Degradation, Bonn, Germany.

Flagg, C.B., Neff, J.C., Reynolds, R.L., Belnap, J., 2014. Spatial and temporal patterns of dust emissions (2004-2012) in semi-arid landscapes, southeastern Utah, USA. Aeolian Research 15, 31-43.

Gillette, D.A., 1999. A qualitative geophysical explanation for "Hot Spot" dust emitting source regions. Contributions to Atmospheric Physics 72, 67-77.

Goebel, J.J., 1998. The National Resources Inventory and Its Role in U.S. Agriculture, Agricultural Statistics 2000, Proceedings of the Conference on Agricultural Statistics Organized by the National Agricultural Statistics Service of the U.S. Department of Agriculture, under the auspices of the International Statistical Institute, pp. 181.

Goossens, D., Offer, Z.Y., London, G., 2000. Wind tunnel and field calibration of five aeolian sand traps. Geomorphology 35, 233-252.

Herrick, J.E., Lessard, V.C., Spaeth, K.E., Shaver, P.L., Dayton, R.S., Pyke, D.A., Jolley, L., Goebel, J.J., 2010. National ecosystem assessments supported by scientific and local knowledge. Frontiers in Ecology and the Environment 8, 403-408.

Herrick, J.E., Van Zee, J.W., McCord, S.E., Courtright, E.M., Karl, J.W., Burkett, L.M., 2015. Monitoring Manual for Grassland, Shrubland, and Savanna Ecosystems, Volume 1: Core Methods, Second Edition. USDA-ARS Jornada Experimental Range, Las Cruces, New Mexico.

Hobbie, J.E., Carpenter, S.R., Grimm, N.B., Gosz, J.R., Seastedt, T.R., 2003. The US Long Term Ecological Research Program. Bioscience 53, 21-32.

Jawson, M.D., Shafer, S.R., Franzluebbers, A.J., Parkin, T.B., Follett, R.F., 2005. GRACEnet: Greenhouse gas reduction through agricultural carbon enhancement network. Soil and Tillage Research 83, 167-172.

Keller, M., Schimel, D.S., Hargrove, W.W., Hoffman, F.M., 2008. A Continental Strategy for the National Ecological Observatory Network. Frontiers in Ecology and the Environment 6, 282-284.

Leys, J.F., McTainsh, G.H., Strong, C.L., Heidenreich, S., Biesaga, K., 2008. DustWatch: using community networks to improve wind erosion monitoring in Australia. Earth Surface Processes and Landforms 33, 1912-1926.

Leys, J.F., Butler, H., Yang, X., Heidenreich, S., 2010. CEMSYS Modelled Wind Erosion, PRN 08081220. NSW Department of Environment, Climate Change and Water, Sydney, Australia.

Li, J., Okin, G.S., Herrick, J.E., Belnap, J., Miller, M.E., Vest, K., Draut, A.E., 2013. Evaluation of a new model of aeolian transport in the presence of vegetation. Journal of Geophysical Research 118, 1-19, doi:10.1002/jgrf.20040, 2013. 
Li, J., Okin, G.S., Tatarko, J., Webb, N.P., Herrick, J.E., 2014. Consistency of wind erosion assessments across land use and land cover types: A critical analysis. Aeolian Research 15, 253-260.

Li, Y., Chappell, A., Nyamdavaa, B., Yu, H., Davaasuren, D., Zoljargal, K., 2015. Cost-effective sampling of ${ }^{137} \mathrm{Cs}$-derived net soil redistribution: Part 1-estimating the spatial mean across scales of variation. Journal of Environmental Radioactivity 141, 97-105.

Macpherson, T., Nickling, W.G., Gillies, J.A., Etymezian, V., 2008. Dust emissions from undisturbed and disturbed supply-limited desert surfaces. Journal of Geophysical Research 113, F02S04, doi:10.1029/2007JF000800, 002008.

Marticorena, B., Bergametti, G., 1995. Modeling the atmospheric dust cycle: 1. Design of a soil-derived dust emission scheme. Journal of Geophysical Research 100, 16,415-16,430.

Marx, S.K., McGowan, H.A., Kamber, B.S., Knight, J.M., Denholm, J., Zawadzki, A., 2014. Unprecedented wind erosion and perturbation of surface geochemistry marks the Anthropocene in Australia. Journal of Geophysical Research 119, 1-17.

Neff, J.C., Ballantyne, A.P., Farmer, G.L., Mahowald, N.M., Conroy, J.L., Landry, C.C., Overpeck, J.T., Painter, T.H., Lawrence, C.R., Reynolds, R.L., 2008. Increasing eolian dust deposition in the western United States linked to human activity. Nature Geoscience 1, 189-195.

Okin, G.S., 2008. A new model of wind erosion in the presence of vegetation. Journal of Geophysical Research 113, F02S10, doi:10.1029/2007JF000758, 002008.

Okin, G.S., Heras, M.M.-d.1., Saco, P.M., Throop, H.L., Vivioni, E.R., Parsons, A.J., Wainwright, J., Peters, D.P.C., 2015. Connectivity in dryland landscapes: shifting concepts of spatial interactions. Frontiers in Ecology and the Environment, 13, 20-27.

Raupach, M.R., Briggs, P.R., Ahmad, N., Edge, V.E., 2001. Endosulfan transport II: Modeling airborne dispersal and deposition by spray and vapor. Journal of Environmental Quality 30, 729-740.

Raupach, M.R., Lu, H., 2004. Representation of land-surface processes in aeolian transport models. Environmental Modelling \& Software 19, 93-112.

Ravi, S., D'Odorico, P., Huxman, T.E., Collins, S.L., 2010. Interactions between soil erosion processes and fires: Implications for the dynamics of fertility islands. Rangeland Ecology and Management 63, 267-274.

Ravi, S., D'Odorico, P., Breshears, D.D., Field, J.P., Goudie, A.S., Huxman, T.E., Li, J., Okin, G.S., Swap, R.J., Thomas, A.D., Van Pelt, S., Whicker, J.J., Zobeck, T.M., 2011. Aeolian processes and the biosphere. Reviews in Geophysics 49, RG3001.

Reheis, M.C., Kihl, R., 1995. Dust deposition in southern Nevada and California, 1984-1989: Relations to climate, source area, and source lithology. Journal of Geophysical Research 100, 8893-8918. 
Robertson, G.P., Allen, V.G., Boody, G., Boose, E.R., Creamer, N.G., Drinkwater, L.E., Gosz, J.R., Lynch, L., Havlin, J.L., Jackson, L.E., Pickett, S.T.A., Pitelka, L., Randall, A., Reed, A.S., Seastedt, T.R., Waide, R.B., Wall, D.H., 2008. Long-term Agricultural Research: A Research, Education, and Extension Imperative. Bioscience 58, 640-645.

Rykiel, E.J., 1996. Testing ecological models: the meaning of validation. Ecological Modelling 90, 229244.

Schaefer, G.L., Cosh, M.H., Jackson, T.J., 2007. The USDA Natural Resources Conservation Service Soil Climate Analysis Network (SCAN). Journal of Atmospheric and Oceanic Technology 24, 2073-2077.

Shao, Y., McTainsh, G.H., Leys, J.F., Raupach, M.R., 1993. Efficiencies of sediment samplers for wind erosion measurement. Australian Journal of Soil Research 31, 519-532.

Shao, Y., 2008. Physics and Modelling of Wind Erosion. Kluwer Academic Publishers, London.

Shao, Y., Wyrwoll, K-H., Chappell, A., Huang, J., Lin, Z., McTainsh, G.H., Mikami, M., Tanaka, T.Y., Wang, X., Yoon, S., 2011a. Dust cycle: An emerging core theme in Earth system science. Aeolian Research 2, 181-204.

Shao, Y., Ishizuka, M., Mikami, M., Leys, J.F., 2011b. Parameterisation of size-resolved dust emission and validation with measurements. Journal of Geophysical Research 116, D08203, doi:10.1029/2010JD014527, 2011.

Shao, Y., Nickling, W., Bergametti, G., Butler, H., Chappell, A., Findlater, P., Gillies, J., Ishizuka, M., Klose, M., Kok, J.F., Leys, J., Lu, H., Marticorena, B., McTainsh, G., McKenna-Neuman, C., Okin, G.S., Strong, C., Webb, N.P., 2015. A tribute to Michael R. Raupach for contributions to aeolian fluid dynamics. Aeolian Research 19, 37-54.

Sharratt, B.S., Lauer, D., 2006. Particulate matter concentration and air quality affected by windblown dust in the Colorado Plateau. Journal of Environmental Quality 35, 2011-2016.

Sharratt, B.S., Tatarko, J., Abatzoglou, J., Fox, F.A., Huggins, D.R., 2015. Implications of climate change on wind erosion of agricultural lands in the Columbia Plateau. Weather and Climate Extremes 10, 1016.

Sharratt, B.S., Vaddella, V.K., 2012. Threshold friction velocity of soils within the Columbia Plateau. Aeolian Research 6, 13-20.

Shinoda, M., Gillies, J.A., Mikami, M., Shao, Y., 2011. Temperature grasslands as a dust source: Knowledge, uncertainties, and challenges. Aeolian Research 3, 271-293.

Sprigg, W.A., Nickovic, S., Galgiana, J.N., Pejanovic, G., Petkovic, S., Vujadinovic, M., Vukovic, A., Dacic, M., DiBiase, S., Prasad, A., El-Askary, H., 2014. Regional dust storm modeling for health services: The case of valley fever. Aeolian Research 14, 53-73. 
Tatarko, J., Sporcic, M.A., Skidmore, E.L., 2013. A history of wind erosion prediction models in the United States Department of Agriculture prior to the Wind Erosion Prediction System. Aeolian Research 10, 3-8.

Toevs, G.R., Karl, J.W., Taylor, J.T., Spurrier, C.S., Karl, M., Bobo, M.R., Herrick, J.E., 2011. Consistent indicators and methods and a scalable sample design to meet assessment, inventory, and monitoring information needs across scales. Rangelands 33, 14-20.

Van Pelt, R.S., Zobeck, T.M., Potter, K.N., Stout, J.E., Popham, T.W., 2004. Validation of the wind erosion stochastic simulator (WESS) and the revised wind erosion equation (RWEQ) for single events. Environmental Modelling \& Software 19, 191-198.

Wagner, L.E., 2013. A history of Wind Erosion Prediction Models in the United States Department of Agriculture: The Wind Erosion Prediction System (WEPS). Aeolian Research 10, 9-24.

Walker, W.E., Harremoës, P., Rotmans, J., Van Der Sluijs, J.P., Van Asselt, M.B.A., Janssen, P., Krayer Von Krauss, M.P., 2003. Defining Uncertainty A conceptual basis for uncertainty management in model-based decision support. Integrated Assessment 4, 5-17.

Webb, N.P., Okin, G.S., Brown, S., 2014. The effect of roughness elements on wind erosion: the importance of surface shear stress distribution. Journal of Geophysical Research: Atmospheres 119, 6066-6084.

Webb, N.P., Herrick, J.E., Van Zee, J.W., Hugenholtz, C.H., Zobeck, T.M., Okin, G.S., 2015. Standard Methods for Wind Erosion Research and Model Development: Protocol for the National Wind Erosion Research Network. USDA-ARS Jornada Experimental Range, Las Cruces, New Mexico.

Webb, N.P., Galloza, M.S., Zobeck, T.M., Herrick, J.E., 2016. Threshold wind velocity dynamics as a driver of aeolian sediment mass flux. Aeolian Research 20, 45-58.

Yumimoto, K., Uno, I., Sugimoto, N., Shimizu, A., Liu, Z., Winker, D.M., 2008. Adjoint inversion modeling of Asian dust emission using lidar observations. Atmospheric Chemistry and Physics 8, 2869-2884.

Zobeck, T.M., 1991. Soil properties affecting wind erosion. Journal of Soil and Water Conservation 46, 112-118.

Zobeck, T.M., Sterk, G., Funk, R., Rajot, J.L., Stout, J.E., Van Pelt, R.S., 2003. Measurement and data analysis methods for field-scale wind erosion studies and model validation. Earth Surface Processes and Landforms 28, 1163-1188. 
Figure 1 - Map showing the locations of the current National Wind Erosion Research Network sites in the contiguous United States. Seven Network sites are coordinated by the USDA Agricultural Research Service (ARS), while four sites are coordinated by the Bureau of Land Management (BLM) in collaboration with the US Geological Survey (USGS) and The Nature Conservancy. The Holloman Air Force Base (DoD) site is currently maintained by the USDA-ARS Jornada Experimental Range. Inset map shows mean annual precipitation (data source: PRISM; Daly et al., 2001).

Figure 2 - Schematic of a National Wind Erosion Research Network site showing the central location of the meteorological tower, vegetation transects, and example random locations of the sediment samplers (27 MWAC masts and 3 dust deposition traps) across the site. Details of the instrumentation and sampling design are provided in Section 3.1 and Table 1.

Figure 3 - A selection of the National Wind Erosion Research Network sites, including (a) Jornada Experimental Range, NM; (b) Big Spring, TX; (c) Central Plains Experimental Range, CO; (d) Holloman Air Force Base, NM; (e) San Luis Valley, CO; (f) Heart Rock Ranch, ID; and (g) Northern Plains, ND.

Figure 4 - Photographs of the National Wind Erosion Research Network site instrumentation, including (a) the $10 \mathrm{~m}$ meteorological tower with cup anemometers, temperature sensors and time-lapse camera, and (b) Sensit HN14-LIN saltation mass flux sensor, (c, f, g) Modified Wilson and Cooke (MWAC) sediment samplers, (d) a field crew learning about the meteorological equipment, and (e) marble-type dust deposition trap.

Figure 5 - Example data visualization tools provided online for each National Wind Erosion Research

698 Network site. Meteorological data are updated hourly by direct transmission from the Network sites to a 699 server maintained at the USDA-ARS Jornada Experimental Range in Las Cruces, NM. The graphs are interactive, allowing users to explore in detail the latest observations, while raw data from all 701 meteorological sensors are publicly available through the Network Data Portal 702 (http://winderosionnetwork.org/data-portal/access-data). 


\section{List of Tables}

706

707 Table 1 - Summary of the National Wind Erosion Research Network measurements, including 708 instrumentation deployment details and minimum data sampling and logging frequencies.

709

710 Table 2 - Summary statistics of vertically integrated horizontal sediment mass flux to $1 \mathrm{~m}$ height above 711 the soil surface, measured at the USDA Jornada Experimental Range National Wind Erosion Research 712 Network site from June 2015 to March 2016.

713

714 Table 3 - Summary of the biophysical characteristics of the National Wind Erosion Research Network 715 sites.

716 
717 Figure 1 - Map showing the locations of the current National Wind Erosion Research Network sites in the 718 contiguous United States. Seven Network sites are coordinated by the USDA Agricultural Research 719 Service (ARS), four sites are coordinated by the Bureau of Land Management (BLM) in collaboration 720 with the US Geological Survey (USGS) and The Nature Conservancy. The Holloman Air Force Base 721 (DoD) site is currently maintained by the USDA-ARS Jornada Experimental Range. Inset map shows 722 mean annual precipitation (data source: PRISM; Daly et al., 2001).

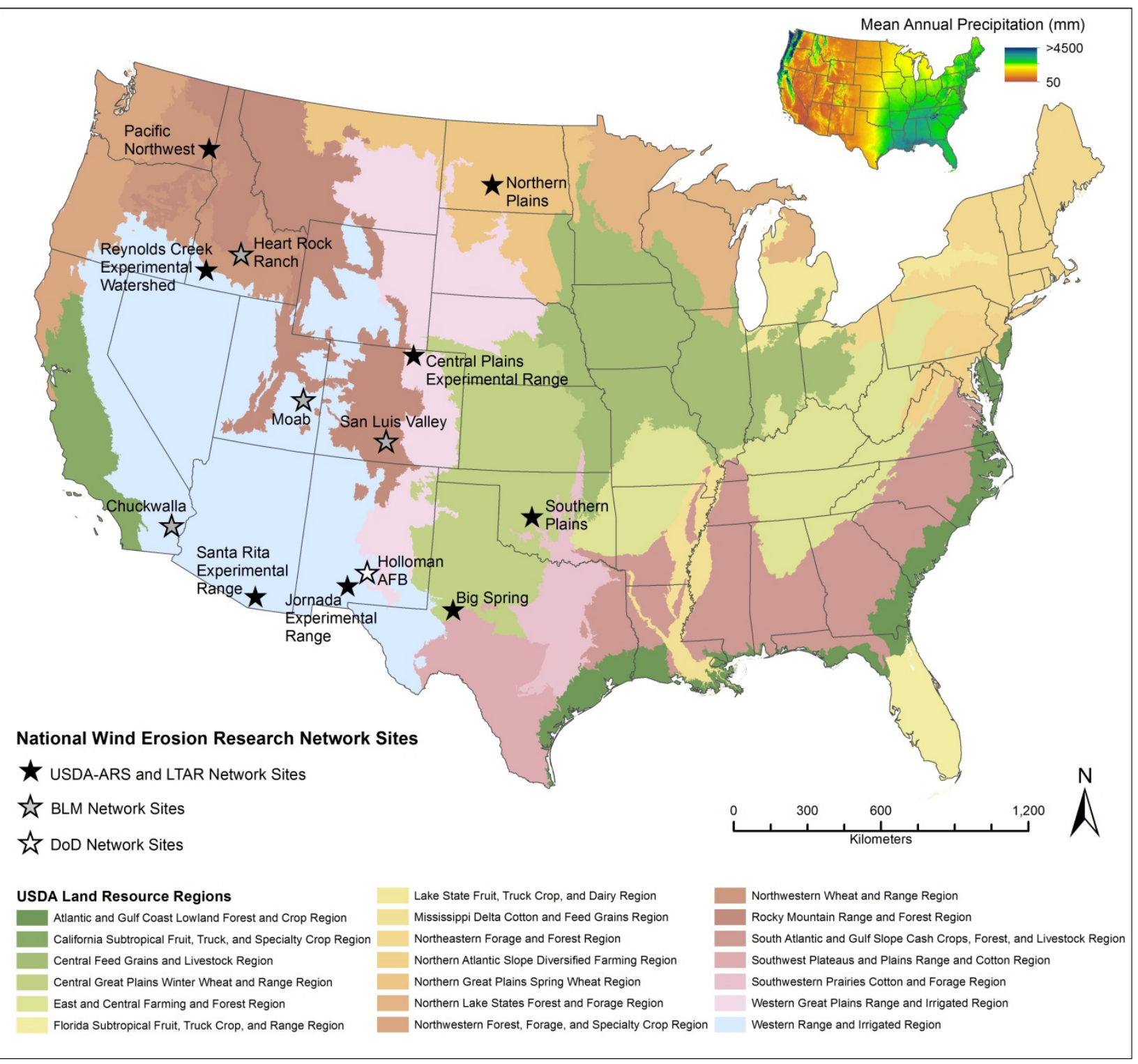


727 Figure 2 - Schematic of a National Wind Erosion Research Network site showing the central location of 728 the meteorological tower, vegetation transects, and example random locations of the sediment samplers 729 (27 MWAC masts and 3 dust deposition traps) across the site. Details of the instrumentation and sampling 730 design are provided in Section 3.1 and Table 1.

731

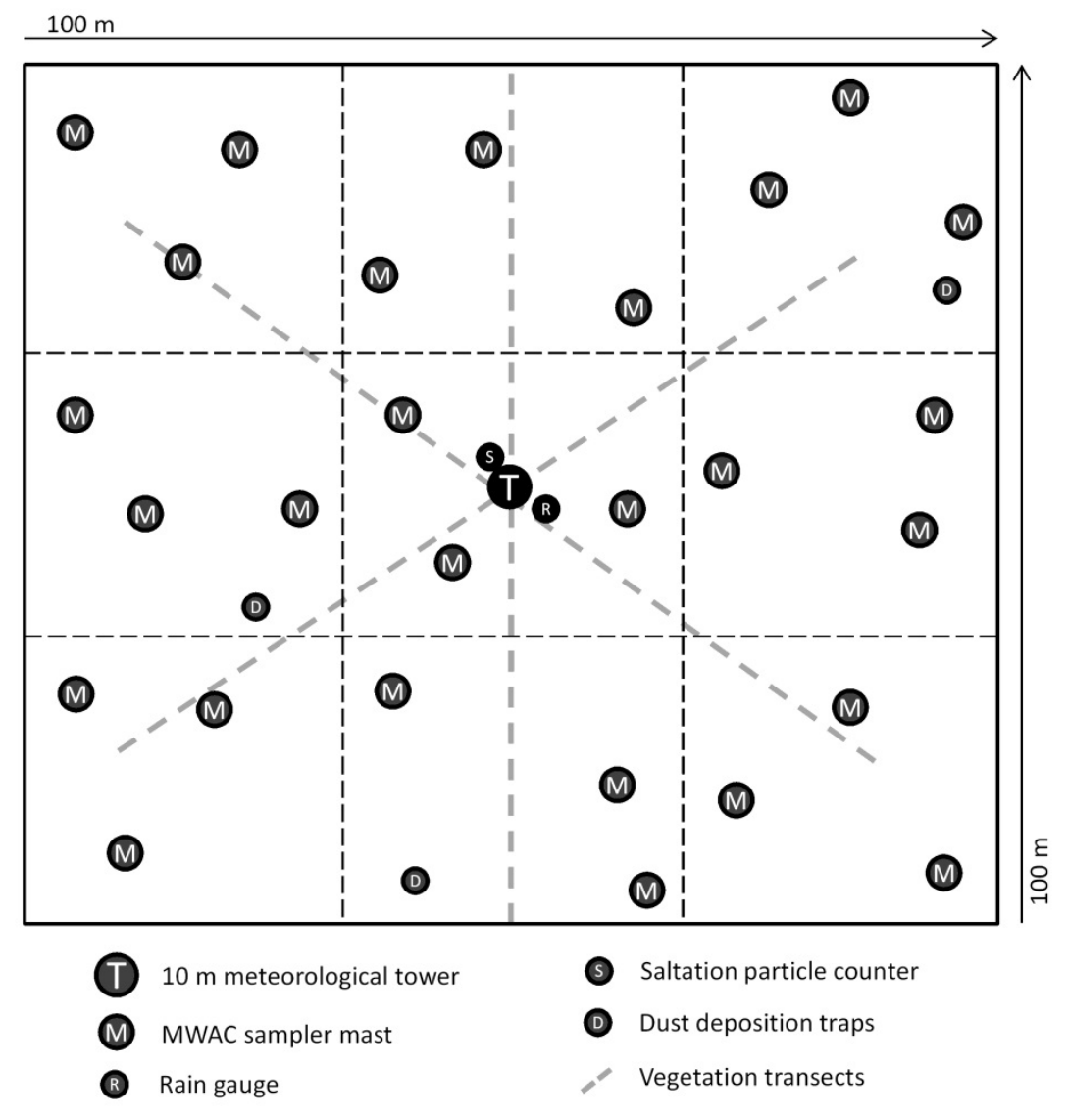


734 Figure 3 - A selection of the National Wind Erosion Research Network sites, including (a) Jornada 735 Experimental Range, NM; (b) Big Spring, TX; (c) Central Plains Experimental Range, CO; (d) Holloman 736 Air Force Base, NM; (e) San Luis Valley, CO; (f) Heart Rock Ranch, ID; and (g) Northern Plains, ND.

737
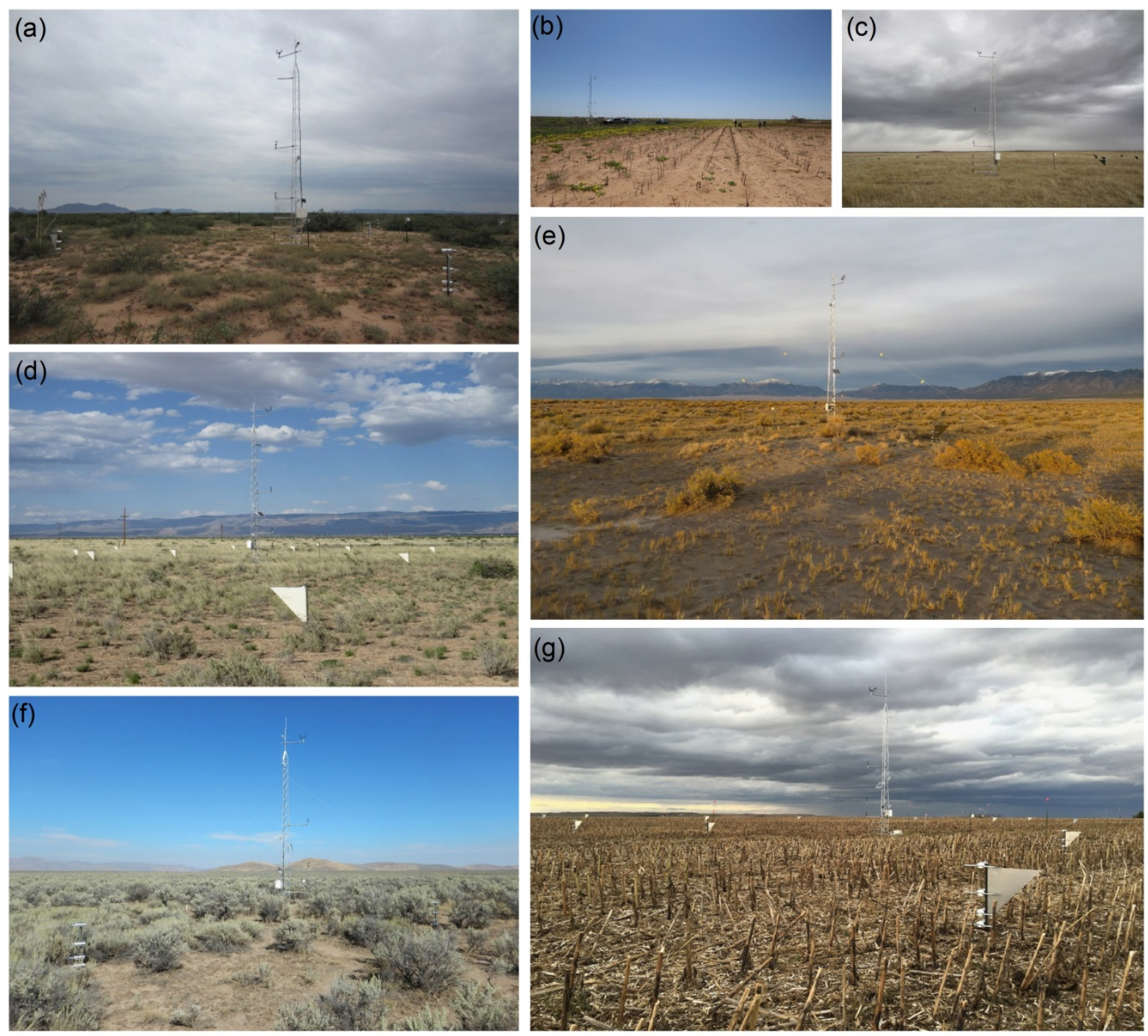
741 Figure 4 - Photographs of the National Wind Erosion Research Network site instrumentation, including 742 (a) the $10 \mathrm{~m}$ meteorological tower with cup anemometers, temperature sensors and time-lapse camera, 743 and (b) Sensit HN14-LIN saltation mass flux sensor, (c, f, g) Modified Wilson and Cooke (MWAC) 744 sediment samplers, (d) a field crew learning about the meteorological equipment, and (e) marble-type dust 745 deposition trap.

746
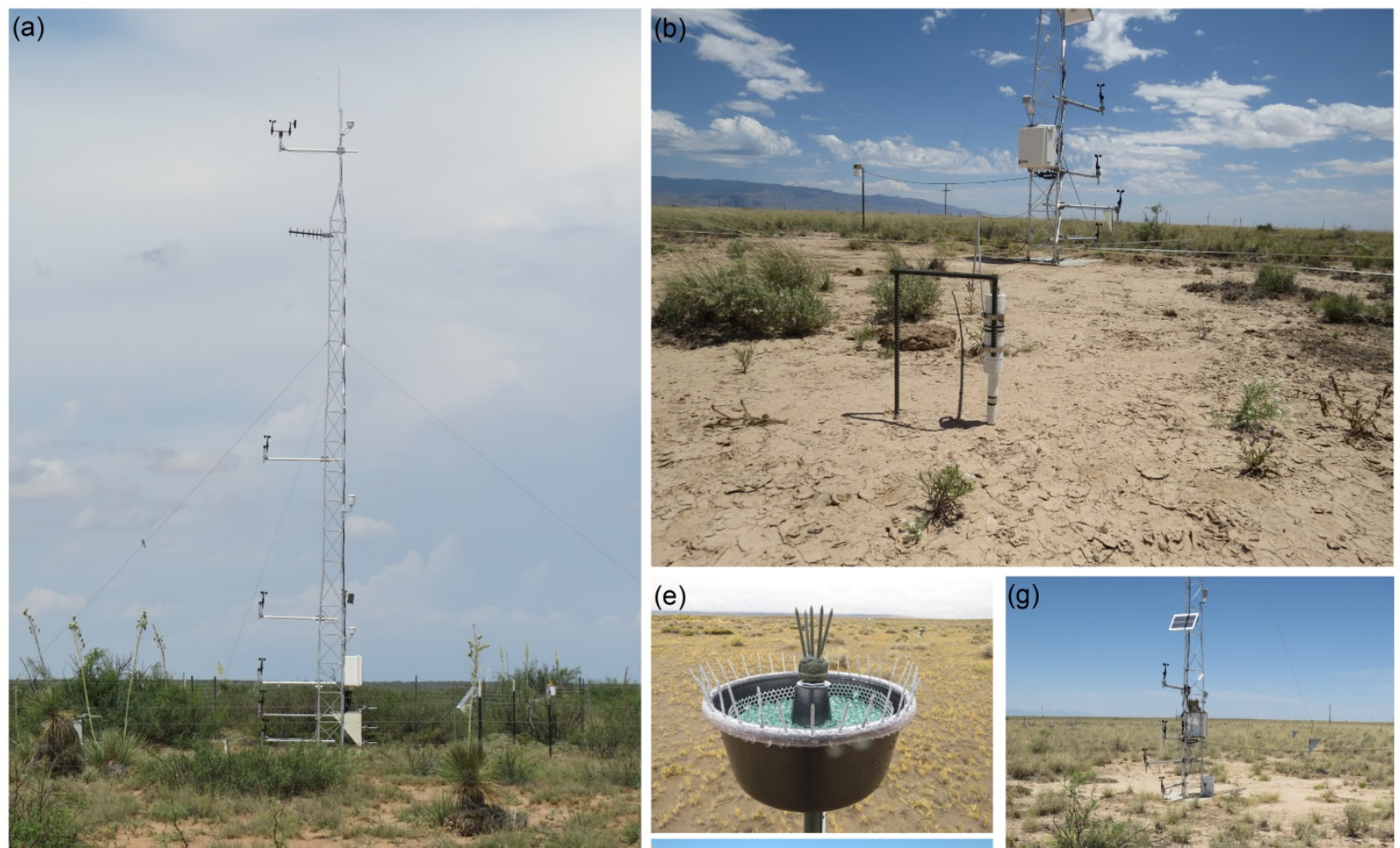

(c)

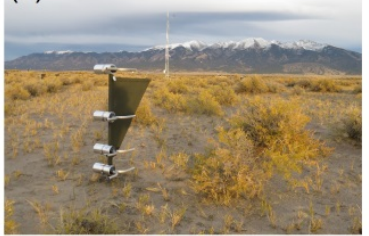

(d)

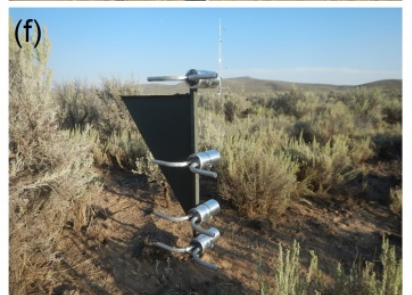

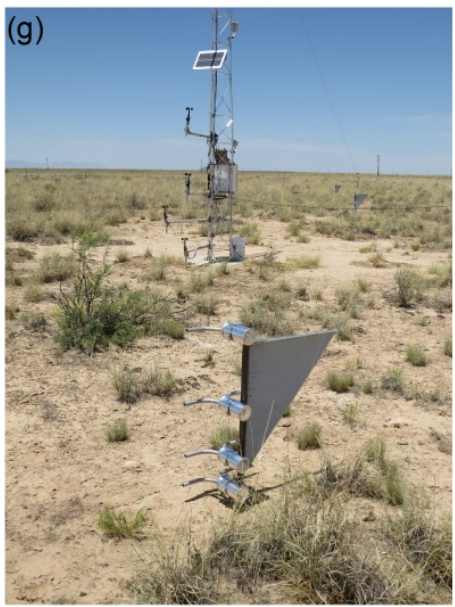


750 Figure 5 - Example data visualization tools provided online for each National Wind Erosion Research

751 Network site. Meteorological data are updated hourly by direct transmission from the Network sites to a 752 server maintained at the USDA-ARS Jornada Experimental Range in Las Cruces, NM. The graphs are 753 interactive, allowing users to explore in detail the latest observations, while raw data from all 754 meteorological sensors are publicly available through the Network Data Portal 755 (http://winderosionnetwork.org/data-portal/access-data).
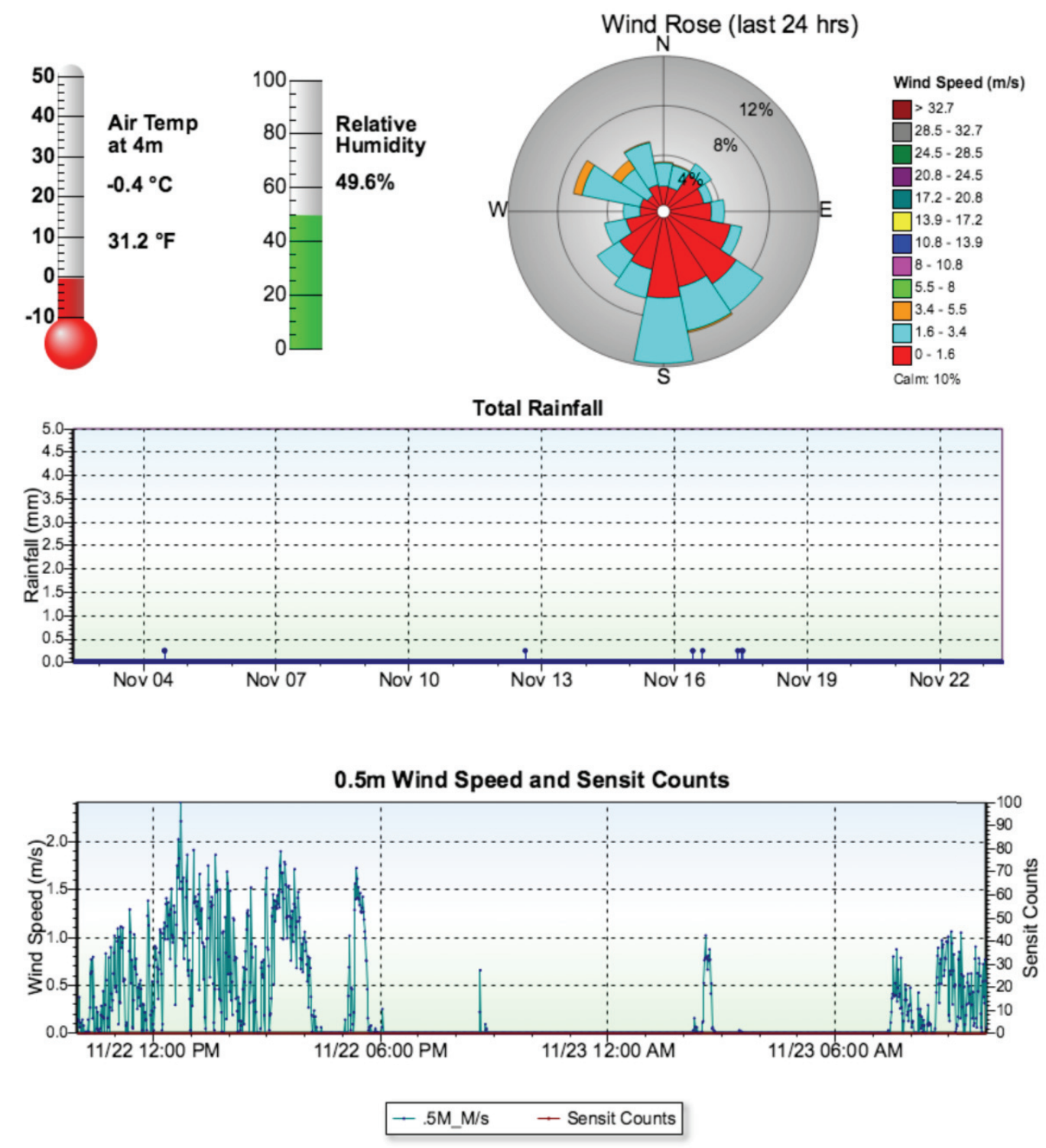
Table 1 - Summary of the National Wind Erosion Research Network measurements, including instrumentation deployment details and minimum data

761 sampling and logging frequencies.

\begin{tabular}{|c|c|c|c|}
\hline Measurement & Instrument & Deployment & Sampling / Logging Frequency \\
\hline \multicolumn{4}{|l|}{ Meteorological } \\
\hline Wind speed / direction & RM Young 3002 & Mounted at $10 \mathrm{~m}$ & $1 \mathrm{~Hz} / 1 \mathrm{~min}$ \\
\hline Wind speed & RM Young 3101 & $\begin{array}{l}\text { Mounted at } 0.5 \mathrm{~m}, 1.0 \mathrm{~m}, 1.5 \mathrm{~m}, 2.5 \\
\mathrm{~m} \text {, and } 5 \mathrm{~m}\end{array}$ & $1 \mathrm{~Hz} / 1 \mathrm{~min}$ \\
\hline Air temperature & 107-L & Mounted at $2 \mathrm{~m}$ and $10 \mathrm{~m}$ & $1 \mathrm{~Hz} / 1 \mathrm{~min}$ \\
\hline Air temperature / relative humidity & Rotronic HygroClip2 HC2S3-L & Mounted at $4 \mathrm{~m}$ & $1 \mathrm{~Hz} / 1 \mathrm{~min}$ \\
\hline Rainfall & Texas Instruments TE525 & Mounted at $1.5 \mathrm{~m}$ & $1 \mathrm{~Hz} / 1 \mathrm{~min}$ \\
\hline Saltation counts & Sensit HN14-LIN & Mounted at $0.05 \mathrm{~m}$ & $1 \mathrm{~Hz} / 1 \mathrm{~min}$ \\
\hline Data logger & Campbell Scientific CR1000-XT-SW & Enclosure, mounted at $1.5 \mathrm{~m}$ & \\
\hline Conversion module & LLAC4-SW & Enclosure, mounted at $1.5 \mathrm{~m}$ & \\
\hline Compact flash memory extension & CFM100 & Enclosure, mounted at $1.5 \mathrm{~m}$ & \\
\hline Modem & RAVENXTV & Enclosure, mounted at $1.5 \mathrm{~m}$ & Hourly data transfer \\
\hline \multicolumn{4}{|l|}{ Sediment Transport } \\
\hline Horizontal mass flux & $\begin{array}{l}\text { Modified Wilson and Cooke } \\
\text { (MWAC) }\end{array}$ & $\begin{array}{l}27 \text { masts each with sampler bottles at } \\
0.1 \mathrm{~m}, 0.25 \mathrm{~m}, 0.5 \mathrm{~m} \text { and } 0.85 \mathrm{~m}\end{array}$ & Monthly (minimum) \\
\hline Vertical mass flux & DustTrak $^{\mathrm{TM}}$ DRX model 8533 & Mounted at $2 \mathrm{~m}$ and $4 \mathrm{~m}$ & $1 \mathrm{~Hz} / 1 \mathrm{~min}$ \\
\hline Dust deposition & $\begin{array}{l}\text { Marble-type trap (Reheis and Kihl, } \\
\text { 1995) }\end{array}$ & 3 traps mounted at $1.5 \mathrm{~m}$ & 4 times per year (minimum) \\
\hline \multicolumn{4}{|l|}{ Site Condition } \\
\hline Time-lapse photographs & Reconyx HC500 & Mounted at $2 \mathrm{~m}$ & $\begin{array}{l}5 \text { photographs per day between 11:00 } \\
\text { and 13:00 hrs local time }\end{array}$ \\
\hline Cropland management & & & Recorded on event basis \\
\hline Rangeland management & & & Recorded on event basis \\
\hline \multicolumn{4}{|l|}{ Vegetation / Soil Surface } \\
\hline \multicolumn{3}{|c|}{ Line-point intercept (fractional cover of: vegetation by species, physical/biological crusts, loose erodible material) } & 4 times per year (minimum) \\
\hline \multicolumn{3}{|c|}{ Canopy height } & 4 times per year (minimum) \\
\hline \multicolumn{3}{|l|}{ Canopy gap distribution } & 4 times per year (minimum) \\
\hline \multicolumn{3}{|l|}{ Oriented soil roughness } & Incorporated into management record \\
\hline
\end{tabular}


Table 2 - Summary statistics of vertically integrated horizontal sediment mass flux to $1 \mathrm{~m}$ height above the soil surface, measured at the USDA Jornada Experimental Range National Wind Erosion Research Network site from June 2015 to March 2016.

\begin{tabular}{llllllll}
\hline & \multicolumn{6}{c}{ Vertically Integrated Horizontal Sediment Mass Flux $\left(\mathrm{g} \mathrm{m}^{-1}\right.$ day $\left.^{-1}\right)$} \\
\hline Collection Date & $\mathrm{n}$ & Mean & Median & Min & Max & SD & CV \\
\hline $2015-06-24$ & 26 & 23.82 & 16.31 & 1.77 & 68.96 & 20.22 & 84.87 \\
$2015-07-31$ & 23 & 53.81 & 42.04 & 15.21 & 157.09 & 32.70 & 60.77 \\
$2015-08-26$ & 21 & 29.02 & 17.12 & 3.14 & 218.19 & 45.42 & 156.53 \\
$2015-09-22$ & 14 & 42.07 & 4.40 & 1.65 & 518.01 & 137.03 & 325.68 \\
$2015-10-22$ & 7 & 17.40 & 18.00 & 3.15 & 35.77 & 13.07 & 75.08 \\
$2015-11-24$ & 27 & 136.16 & 106.94 & 18.48 & 605.29 & 142.23 & 104.46 \\
$2015-12-22$ & 27 & 20.35 & 12.08 & 1.66 & 89.32 & 20.67 & 101.57 \\
$2016-01-27$ & 27 & 31.22 & 18.83 & 3.27 & 175.66 & 38.51 & 123.34 \\
$2016-02-23$ & 27 & 122.89 & 92.22 & 21.60 & 399.54 & 107.12 & 87.17 \\
$2016-03-21$ & 26 & 31.19 & 24.33 & 6.41 & 115.43 & 26.75 & 85.78
\end{tabular}

Note: SD and CV are the standard deviation and coefficient of variation respectively. $\mathrm{n}=$ number of sediment samplers for which horizontal sediment mass flux could be established for each sampling

768 period. 
Table 3 - Summary of the biophysical characteristics of the National Wind Erosion Research Network sites.

\begin{tabular}{|c|c|c|c|c|c|c|c|c|c|}
\hline Site (Affiliations ${ }^{\#}$ ) & Latitude & Longitude & Elevation & Ecoregion & Land Use & Management & $\begin{array}{l}\text { USDA Texture } \\
\text { Class }\end{array}$ & $\begin{array}{l}\text { Soil Map Unit } \\
\text { Components* }\end{array}$ & Vegetation - Dominant Species \\
\hline Big Spring, TX (ARS) & 32.0267 & -101.7995 & $805 \mathrm{~m}$ & $\begin{array}{l}\text { Texas High } \\
\text { Plains }\end{array}$ & Cropland & $\begin{array}{l}\text { Conventional } \\
\text { tillage }\end{array}$ & Loamy fine sand & Springer & $\begin{array}{l}\text { Cotton (Gossypium hirsutum L.) } \\
\text { Sorghum (Sorghum bicolor }(\mathrm{L} .) \\
\text { Moensch.) }\end{array}$ \\
\hline $\begin{array}{l}\text { Central Plains } \\
\text { Experimental Range, } \\
\text { CO (LTAR) }\end{array}$ & 40.8348 & -104.6972 & $1636 \mathrm{~m}$ & $\begin{array}{l}\text { Central High } \\
\text { Plains }\end{array}$ & $\begin{array}{l}\text { Rangeland and } \\
\text { Cropland } \\
\text { (planned) }\end{array}$ & $\begin{array}{l}\text { Livestock } \\
\text { grazing }\end{array}$ & Fine sandy loam & Ascalon & $\begin{array}{l}\text { Blue grama (Bouteloua gracilis (Willd. } \\
\text { ex Kunth) Lag. ex Griffiths) } \\
\text { Sand dropseed (Sporobolus cryptandrus } \\
\text { (Torr.) A. Gray) } \\
\text { Squirreltail (Elymus elymoides (Raf.) } \\
\text { Swezey) }\end{array}$ \\
\hline Chuckwalla, CA (BLM) & 33.6592 & -115.1013 & $116 \mathrm{~m}$ & $\begin{array}{l}\text { Mojave } \\
\text { Desert }\end{array}$ & Desert & $\begin{array}{l}\text { Nearby solar } \\
\text { energy plants }\end{array}$ & $\begin{array}{l}\text { Sandy/ } \\
\text { Loamy sand }\end{array}$ & $\begin{array}{l}\text { Carsitas/ } \\
\text { Rositas }\end{array}$ & $\begin{array}{l}\text { Creosote bush (Larrea tridentata (DC.) } \\
\text { Coville) } \\
\text { Burrobush (Ambrosia dumosa (A. Gray) } \\
\text { Payne) }\end{array}$ \\
\hline $\begin{array}{l}\text { Great Basin - Boise, ID } \\
\text { (LTAR) }\end{array}$ & 43.1690 & -116.7129 & $1292 \mathrm{~m}$ & $\begin{array}{l}\text { Owyhee } \\
\text { Uplands }\end{array}$ & Rangeland & $\begin{array}{l}\text { Livestock } \\
\text { grazing }\end{array}$ & $\begin{array}{l}\text { Loam/ } \\
\text { Silt loam }\end{array}$ & $\begin{array}{l}\text { Arbidge/ } \\
\text { Owsel// } \\
\text { Garpier }\end{array}$ & $\begin{array}{l}\text { Wyoming big sagebrush (Artemisia } \\
\text { tridentata Nutt. subsp. wyomingensis } \\
\text { Beetle \& Young) } \\
\text { Little sagebrush (Artemisia arbuscula } \\
\text { Nutt.) } \\
\text { Sandberg bluegrass (Poa secunda J. } \\
\text { Presl) } \\
\text { Squirreltail (Elymus elymoides (Raf.) } \\
\text { Swezey) } \\
\text { Idaho fescue (Festuca idahoensis Elmer) } \\
\text { Bluebunch wheatgrass (Pseudoroegneria } \\
\text { spicata (Pursh) A. Love) }\end{array}$ \\
\hline $\begin{array}{l}\text { Heart Rock Ranch - } \\
\text { Bellevue, ID } \\
\text { (BLM/TNC) }\end{array}$ & 43.3168 & -114.3488 & $1499 \mathrm{~m}$ & $\begin{array}{l}\text { Owyhee } \\
\text { Uplands }\end{array}$ & Rangeland & $\begin{array}{l}\text { Livestock } \\
\text { grazing }\end{array}$ & Loamy & Muldoon & $\begin{array}{l}\text { Mountain big sagebrush (Artemisia } \\
\text { tridentata Nutt. subsp. vaseyana (Rydb.) } \\
\text { Beetle) } \\
\text { Threetip sagebrush (Artemisia tripartita } \\
\text { Rydb.) } \\
\text { Rubber rabbitbrush (Ericameria } \\
\text { nauseosa (Pall. ex Pursh) G.L. Nesom \& } \\
\text { Baird) } \\
\text { Idaho fescue (Festuca idahoensis Elmer) } \\
\text { Crested wheatgrass (Agropyron cristatum } \\
\text { (L.) Gaertn.) }\end{array}$ \\
\hline
\end{tabular}




\begin{tabular}{|c|c|c|c|c|c|c|c|c|c|}
\hline $\begin{array}{l}\text { Holloman AFB, NM } \\
\text { (DoD) }\end{array}$ & 32.9422 & -106.1073 & $1267 \mathrm{~m}$ & $\begin{array}{l}\text { Chihuahuan } \\
\text { Desert }\end{array}$ & $\begin{array}{l}\text { Rangeland } \\
\text { (Protected } \\
\text { Military) }\end{array}$ & $\begin{array}{l}\text { Light grazing } \\
\text { by livestock } \\
\text { and antelope }\end{array}$ & $\begin{array}{l}\text { Gypsiferous } \\
\text { sandy loam }\end{array}$ & Yesum & $\begin{array}{l}\text { Alkali sacaton (Sporobolus airoides } \\
\text { (Torr.) Torr.) } \\
\text { Gyp dropseed (Sporobolus nealleyi } \\
\text { Vasey) } \\
\text { Four-wing saltbush (Atriplex canescens } \\
\text { (Pursh) Nutt.) } \\
\text { Honey mesquite (Prosopis glandulosa } \\
\text { Torr.) }\end{array}$ \\
\hline $\begin{array}{l}\text { Jornada Experimental } \\
\text { Range, NM (LTAR) }\end{array}$ & 32.6271 & -106.7385 & $1324 \mathrm{~m}$ & $\begin{array}{l}\text { Chihuahuan } \\
\text { Desert }\end{array}$ & Rangeland & $\begin{array}{l}\text { Livestock } \\
\text { grazing }\end{array}$ & Sandy loam & Doña Ana & $\begin{array}{l}\text { Dropseed (Sporobolus spp. R. Br.) } \\
\text { Tobosa grass (Pleuraphis mutica } \\
\text { Buckley) } \\
\text { Black grama (Bouteloua eriopoda (Torr.) } \\
\text { Torr.) } \\
\text { Burrograss (Scleropogon brevifolius } \\
\text { Phil.) } \\
\text { Honey mesquite (Prosopis glandulosa } \\
\text { Torr.) } \\
\text { Soaptree yucca (Yucca elata (Engelm.) } \\
\text { Engelm.) }\end{array}$ \\
\hline $\begin{array}{l}\text { Moab, UT } \\
\text { (BLM/USGS) }\end{array}$ & 38.6533 & -109.8623 & $1575 \mathrm{~m}$ & Canyonlands & Rangeland & $\begin{array}{l}\text { Livestock } \\
\text { grazing, } \\
\text { recreation, oil } \\
\text { and gas } \\
\text { production }\end{array}$ & Sandy loam & Begay & $\begin{array}{l}\text { Indian ricegrass (Achnatherum } \\
\text { hymenoides (Roem. \& Schult) } \\
\text { Barkworth) } \\
\text { Needle and thread (Hesperostipa comata } \\
\text { (Trin. \& Rupr.) Barkworth) } \\
\text { Sand dropseed (Sporobolus cryptandrus } \\
\text { (Torr.) A. Gray) } \\
\text { Galleta (Pleuraphis jamesii Torr.) } \\
\text { Ephedra (Ephedra spp. L.) } \\
\text { Four-wing saltbush (Atriplex canescens } \\
\text { (Pursh) Nutt.) }\end{array}$ \\
\hline $\begin{array}{l}\text { Northern Plains - } \\
\text { Mandan, ND (LTAR) }\end{array}$ & 46.7746 & -100.9502 & $593 \mathrm{~m}$ & $\begin{array}{l}\text { Temperate } \\
\text { Steppe }\end{array}$ & Cropland & No till & Silt loam & Wilton & $\begin{array}{l}\text { Sunflower (Helianthus annuus L.) } \\
\text { Soybean (Glycine max (L.) Merr.) } \\
\text { Canola (Brassica napus L.) }\end{array}$ \\
\hline $\begin{array}{l}\text { Pacific Northwest - } \\
\text { Pullman, WA (LTAR) }\end{array}$ & 46.8930 & -118.2887 & $489 \mathrm{~m}$ & $\begin{array}{l}\text { Columbia } \\
\text { Plateau }\end{array}$ & Cropland & $\begin{array}{l}\text { Conventional } \\
\text { tillage }\end{array}$ & Silt loam & Ritzville & Wheat (Triticum aestivum L.) \\
\hline $\begin{array}{l}\text { San Luis Valley, CO } \\
\text { (BLM) }\end{array}$ & 37.5990 & -105.6907 & $2297 \mathrm{~m}$ & $\begin{array}{l}\text { Upper Rio } \\
\text { Grande } \\
\text { Basin }\end{array}$ & Rangeland & $\begin{array}{l}\text { Light grazing } \\
\text { by livestock } \\
\text { and antelope }\end{array}$ & Loamy fine sand & $\begin{array}{l}\text { Space City/ } \\
\text { Hooper/ } \\
\text { Corlett }\end{array}$ & $\begin{array}{l}\text { Greasewood (Sarcobatus vermiculatus } \\
\text { (Hook.) Torr.) } \\
\text { Saltgrass (Distichlis spicata (L.) Greene) } \\
\text { Rubber rabbitbrush (Ericameria } \\
\text { nauseosa (Pall. ex Pursh) G.L. Nesom \& } \\
\text { Baird) } \\
\text { Sandhill muhly (Muhlenbergia pungens } \\
\text { Thurb.) }\end{array}$ \\
\hline
\end{tabular}




\begin{tabular}{|c|c|c|c|c|c|c|c|c|c|}
\hline $\begin{array}{l}\text { Santa Rita Experimental } \\
\text { Range, AZ (LTAR) }\end{array}$ & 31.8150 & -110.8491 & $1177 \mathrm{~m}$ & $\begin{array}{l}\text { Sonoran } \\
\text { Desert } \\
\text { Transition }\end{array}$ & Rangeland & $\begin{array}{l}\text { Livestock } \\
\text { grazing }\end{array}$ & Sandy loam & Sasabe & $\begin{array}{l}\text { Velvet mesquite (Prosopis velutina } \\
\text { Wooton) } \\
\text { Lehmann lovegrass (Eragrostis } \\
\text { lehmanniana Nees) } \\
\text { Burroweed (Isocoma tenuisecta Greene) } \\
\text { Prickly pear cactus (Opuntia engelmannii } \\
\text { Salm-Dyck ex Engelm.) } \\
\text { Fishhook barrel cactus (Ferocactus } \\
\text { wislizeni (Engelm.) Britton \& Rose) } \\
\end{array}$ \\
\hline $\begin{array}{l}\text { Southern Plains - El } \\
\text { Reno, OK (LTAR) }\end{array}$ & 35.5485 & -98.0365 & $424 \mathrm{~m}$ & $\begin{array}{l}\text { Central } \\
\text { Rolling Red } \\
\text { Plains }\end{array}$ & Cropland & $\begin{array}{l}\text { Conventional } \\
\text { tillage }\end{array}$ & Silt loam & Pond Creek & Wheat (Triticum aestivum L.) \\
\hline
\end{tabular}

\# Site affiliations include: USDA Agricultural Research Service (ARS), USDA Long-Term Agroecosystem Research (LTAR) network, DOI Bureau of Land

Management (BLM), US Geological Survey (USGS), Department of Defense (DoD), and The Nature Conservancy (TNC).

* Soil Map Unit Components represent individual soils that occur within delineated Soil Map Unit polygons, as mapped by the U.S. Department of Agriculture (USDA) Natural Resources Conservation Service. 